\title{
Front Matter: Volume 11867
}

, "Front Matter: Volume 11867," Proc. SPIE 11867, Technologies for Optical Countermeasures XVIII and High-Power Lasers: Technology and Systems, Platforms, Effects V, 1186701 (6 October 2021); doi: 10.1117/12.2614935

SPIE. Event: SPIE Security + Defence, 2021, Online Only 


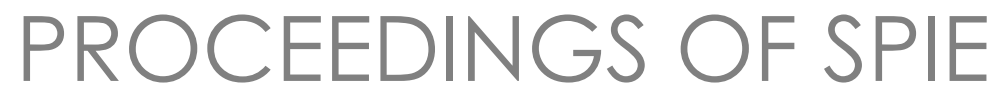

\title{
Technologies for Optical Countermeasures XVIII and High-Power Lasers: Technology and Systems, Platforms, Effects $V$
}

\author{
D. H. Titterton \\ R. J. Grasso \\ M. A. Richardson \\ W. L. Bohn \\ H. Ackermann \\ Editors
}

13-17 September 2021

Online Only, Spain

Sponsored by

SPIE

Cooperating Organisations

European Optical Society • Cranfield University (United Kingdom) • CENSIS (United Kingdom) • SEDOPTICA (Spain)

Supporting Organisation

INEUSTAR/INDUCIENCIA (Spain)

Published by

SPIE

Volume 11867 
The papers in this volume were part of the technical conference cited on the cover and title page. Papers were selected and subject to review by the editors and conference program committee. Some conference presentations may not be available for publication. Additional papers and presentation recordings may be available online in the SPIE Digital Library at SPIEDigitalLibrary.org.

The papers reflect the work and thoughts of the authors and are published herein as submitted. The publisher is not responsible for the validity of the information or for any outcomes resulting from reliance thereon.

Please use the following format to cite material from these proceedings:

Author(s), "Title of Paper," in Technologies for Optical Countermeasures XVIII and High-Power Lasers: Technology and Systems, Platforms, Effects V, edited by D. H. Titterton, R. J. Grasso, M. A. Richardson, W. L. Bohn, H. Ackermann, Proc. of SPIE 11867, Seven-digit Article CID Number (DD/MM/YYYY); (DOI URL).

ISSN: 0277-786X

ISSN: 1996-756X (electronic)

ISBN: 9781510645783

ISBN: 9781510645790 (electronic)

Published by

SPIE

P.O. Box 10, Bellingham, Washington 98227-0010 USA

Telephone +1 3606763290 (Pacific Time)

SPIE.org

Copyright (C) 2021 Society of Photo-Optical Instrumentation Engineers (SPIE).

Copying of material in this book for internal or personal use, or for the internal or personal use of specific clients, beyond the fair use provisions granted by the U.S. Copyright Law is authorized by SPIE subject to payment of fees. To obtain permission to use and share articles in this volume, visit Copyright Clearance Center at copyright.com. Other copying for republication, resale, advertising or promotion, or any form of systematic or multiple reproduction of any material in this book is prohibited except with permission in writing from the publisher.

Printed in the United States of America by Curran Associates, Inc., under license from SPIE.

Publication of record for individual papers is online in the SPIE Digital Library.

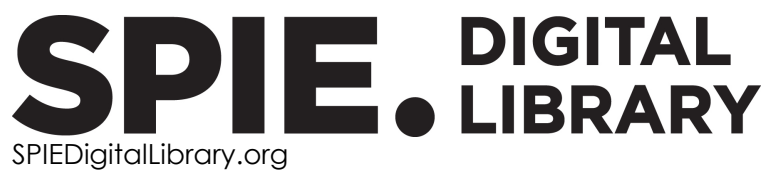

Paper Numbering: A unique citation identifier (CID) number is assigned to each article in the Proceedings of SPIE at the time of publication. Utilization of CIDs allows articles to be fully citable as soon as they are published online, and connects the same identifier to all online and print versions of the publication. SPIE uses a seven-digit CID article numbering system structured as follows:

- The first five digits correspond to the SPIE volume number.

- The last two digits indicate publication order within the volume using a Base 36 numbering system employing both numerals and letters. These two-number sets start with 00, 01, 02, 03, 04, $05,06,07,08,09,0 A, 0 B \ldots 0 Z$, followed by 10-1Z, 20-2Z, etc. The CID Number appears on each page of the manuscript. 


\section{Contents}

PANEL DISCUSSION: LASER WEAPONS AND LASERS USED AS WEAPONS AGAINST PERSONNEL

1186704 Smoke as protection against high energy laser effects (Keynote Paper) [1 1867-1]

\section{LASER EFFECTS}

1186707 The potential role of laser in combating UAVs: part 2; laser as a countermeasure and weapon (Invited Paper) [1 1867-4]

$1186708 \quad$ Nanostructured biocompatible Ti-TiN coating for implants with improved functional properties [11867-5]

1186709 Real-time monitoring of wire electro-discharge machining semiconducting composite ceramics $\mathrm{TiC}+\mathrm{Al}_{2} \mathrm{O}_{3}[11867-6]$

11867 OA A new method for efficiently controlling energy use in Electrical Discharge Machining (EDM) [11867-7]

BEAM STEERING, POINTING, AND CONTROL

11867 OD Aberration and coherence effects with a micromirror array (Invited Paper) [1 1867-10]

$11867 \mathrm{OE} \quad$ Outdoor target-in-the-loop coherent beam combination using a stochastic parallel gradient descent algorithm [1 1867-11]

\section{LASER AGAINST PERSONNEL}

11867 OF Simulating laser dazzling using augmented and virtual reality [11867-12]

\section{LASER ARCHITECTURES FOR POWER SCALING}

11867 OG System assessment capability for the laser effector (Invited Paper) [1 1867-13] 
FIBER LASERS AND BEAM COMBINING

$11867 \mathrm{OH} \quad$ Coherent combining of 7 fiber lasers using a multi-plane light converter device (Invited Paper) [1 1867-14]

11867 OJ Monolithic freeform optic arrays for low-SWaP laser directed energy effectors [1 1867-16]

$11867 \mathrm{OL} \quad 1800-2400 \mathrm{~nm}$ OPCPA based on BiBO with signal-to-idler conversion by transient stimulated Raman chirped pulse amplification [1 1867-18]

DIODE PUMPED ALKALI LASERS (DIPAL)

11867 ON Modeling of K and Rb DPALs (Invited Paper) [1 1867-20]

LASER INTERACTION, EFFECTS, AND COMPONENTS

1186700 Terahertz emission from a single-color laser filament plasma (Invited Paper) [1 1867-21]

11867 OP Spectroscopy as diagnostic tool to investigate the HEL-material interaction [1 1867-22]

POSTER SESSION: TECHNOLOGIES FOR OPTICAL COUNTERMEASURES

11867 OS Reverse engineering of geometric models of advanced curved edge drills using optical measuring systems [1 1867-25]

11867 OT Research on the relationship between photothermal effect and wavelength of laser beam in gastric tumor [11867-26]

iv 